\title{
PEMANFAATAN TEKNOLOGI RFID MELALUI KARTU IDENTITAS UNTUK LINGKUNGAN KANTOR
}

\author{
Muhammad Reza \\ Email: MrMuhammadReza@gmail.com \\ Received : 31 Oktober 2019 ; Accepted :
}

\begin{abstract}
s
As time goes on, technology become more advance. It makes everything simpler, thinner, and well organized. Even your money can be replaced by a single card. One of the latest system invented is Radio Frequency Identification or RFID. This system need media like smart chippedcard or nametag for emitting signal which then received by a tool called receiver / reader. In the office environment, RFID has a major role to create better supervision for empolyee and security. It can record attendance, give authorization to access, or even record bio data for manajement purpose. This RFID application in office is expected to make faster production and well-organized management.
\end{abstract}

Keywords : RFID, Office, Security, Supervision

\begin{abstract}
Abstrak
Seiring dengan bertambahnya waktu, teknologi semakin lama semakin maju. Teknologi membuat semuanya menjadi lebih mudah, semakin tipis, dan semakin mudah diatur. Bahkan uangmu bisa digantikan dengan sebuah kartu. Salah satu sistem terbaru yang pernah dibuat adalah RFID atau identifikasi dengan menggunakan frekuensi radio. Sistem ini memerlukan media seperti kartu chip pintar atau tag nama untuk mengeluarkan sinyal dimana nantinya diterima oleh receiver / reader. Pada lingkungan kantor, RFID punya andil besar untuk menciptakan pengawasan yang baik untuk karyawan dan keamanan. RFID dapat merekam absen, memberikan otoritas, atau bahkan merekam biodata untuk tujuan manajerial. Pengaplikasian RFID pada kantor diharapkan dapat membuat cepat produksi dan manajemen.
\end{abstract}

Kata Kunci : RFID, Kantor, Sekuritas, Pengawasan

\section{PENDAhuluan}

Perkembangan ilmu pengetahuan khususnya dalam hal iptek, membuat banyak terobosan ke dalam banyak bidang. Perkembangan ini menuju kearah yang lebih baik dalam hal keefektifitasan dan keefisiensian. Contohnya pada zaman dahulu, komputer pertama kali dibuat mempunyai bentuk dan bobot sangat besar. Sedangkan pada zaman sekarang, sudah ada laptop yang bentuknya super tipis, efektif jika dibawa kemana-mana, jauh lebih murah, bahkan hemat energi.
Dalam dunia kerja, adanya perkembangan iptek membuat pekerjaan menjadi mudah dan cepat, produktivitas meningkat, penghematan biaya dan sumber daya, ajang promosi lebih efektif, sistem kontrol dan pengawasan yang baik, menciptakan suasana kerja yang nyaman dan kondusif serta menjaga keteraturan dalam manajemen dan penyimpanan data. Dengan menggunakan teknologi yang tepat guna, suatu perusahaan bisa mendapat margin keuntungan berlipat ganda dengan biaya relatif murah dan sumber daya yang minim. 
Salah satu jenis teknologi tepat guna yang bisa diterapkan pada suasana kantor adalah teknologi yang berbasis pada informasi atau teknologi informasi. Teknologi ini menggabungkan komputasi (komputer) dengan jalur komunikasi berkecepatan tinggi yang membawa data, suara, serta video. Teknologi informasi sendiri adalah istilah umum yang menjelaskan teknologi apapun yang membantu manusia dalam membuat, mengubah, menyimpan, mengomunikasikan dan menyebarkan informasi[1]. Contoh teknologi informasi yang dapat diaplikasikan pada masa sekarang ini di Indonesia adalah RFID (Radio Frequency Identification) atau identifikasi menggunakan frekuensi radio.

RFID sudah banyak digunakan pada kebanyakan perusahaan, pabrik, kantorkantor pemerintah, dan fasilitas publik khususnya dalam bentuk nametag atau kartu nama. Contoh paling umum penggunaan RFID adalah pada E-KTP (Kartu Tanda Penduduk). Keuntungan menggunakan kartu nama berbasis RFID adalah cepatnya birokrasi, menjaga keamanan, serta mencegah manipulasi khususnya pada absensi atau kehadiran. Pengadaan kartu nama ini juga tidak terlalu memakan banyak sumber daya, tanpa efek samping, bahkan cenderung minim emisi, sehingga kartu nama berbasis RFID sangat cocok digunakan oleh semua kalangan.

\section{DEFINISI RFID}

RFID adalah sebuah teknologi nirkabel yang mempunyai kemampuan untuk bertukar informasi antara Tag dan reader/writer ${ }^{[2]}$. Umumnya RFID bergerak dengan menggunakan sinyal radio. RFID mempunyai komponen sebagai berikut:

- Label atau Tag/s atau Transponder (Transmitter Responder).

- Pembaca atau Reader atau Interrogators.

- Perangkat lunak atau software.

- Host atau perangkat yang terhubung ke dalam sistem jaringannya.

Berikut adalah diagram dari sistem RFID:

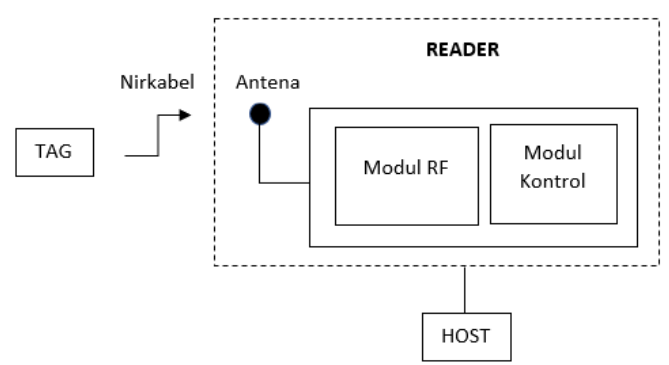

Gambar 1. Diagram Sistem RFID

Prinsip kerja dari sistem ini adalah pertama tag didekatkan ke pembaca. Jika sinyal gelombang radio yang dipancarkan dari antena pembaca menjangkau antena label, maka cip dalam label akan aktif dan mengirimkan respon balik dan data dalam bentuk sinyal gelombang radio ke pembaca. Sinyal yang tertangkap dalam pembaca akan diteruskan ke host untuk ditampilkan isi datanya.

\section{LABEL}

Label (tag) adalah piranti yang mudah dibawa atau dikenakan pada objek agar dapat diidentifikasi oleh pembaca. Label terdiri atas 2 bagian yaitu cip (chip) dan antena (pemancar) yang dibungkus dengan material tertentu agar tidak mudah rusak.

Berdasarkan sumber tenaganya, label terbagi atas 3 macam. Yaitu aktif, semipasif, dan pasif. Label yang aktif menggunakan baterai untuk mengaktifkan label dan mengeluarkan sinyalnya sendiri dalam hal ini pembaca tidak mengeluarkan sinyal sama sekali. Label ini umumnya berukuran besar dan lebih mahal. Label yang pasif menggunakan sinyal dari pembaca untuk mengaktifkan label dan memberikannya tenaga untuk mengirimkan sinyal dan data. Label ini umumnya sangat tipis dan lebih murah. Sedangkan label yang semi-pasif menggunakan baterai dan sinyal dari pembaca untuk mengaktifkan label dan mengeluarkan sinyal. Umumnya label di Indonesia menggunakan sumber tenaga pasif.

Berdasarkan atributnya, label bisa dibedakan menjadi dua. Yaitu read-only atau hanya bisa dibaca serta tidak bisa diganti atau dihapus bahkan dengan menggunakan software khusus pada host sekalipun. 
Dikarenakan lebih murah, label jenis ini cocok untuk banyak objek dengan data-data yang tidak akan berubah. Contoh datanya adalah NIK, NIP, ID unik, nama, tanggal lahir, dan sebagainya.

Atribut yang kedua adalah Read-Write atau dapat dilihat, diubah, dan dihapus. Contoh label yang menggunakan atribut ini adalah label pada ternak untuk mendata berat badan secara periodik atau pendataan stok barang.

\section{KARTU RFID}

Contoh paling umum label yang digunakan di Indonesia untuk lingkungan perkantoran adalah kartu RFID. Kartu ini mempunyai bentuk sangat tipis, setipis kartu ATM atau KTP. Oleh karena medianya yang tipis, tidak mudah rusak, fleksible dan murah, kartu RFID sangat cocok dan populer dipakai untuk mengidentifikasi pegawai.

Kartu RFID sendiri sudah digunakan di banyak bidang di Indonesia. Pada bidang kepegawaian, kartu RFID yang umumnya dipakai yaitu:

a. Kartu RFID Proximity (Contactless Smart Card)

Kartu jenis ini biasanya menggunakan frekuensi $125 \mathrm{KHz}$ (low frequency). Jangkauan kartunya sampai dengan 10 $\mathrm{cm}$. Selain ID unik atau nomor pabriknya, kartu ini tidak dapat menyimpan data, sehingga jika ingin mendata harus melalui pembaca-nya. Kartu jenis ini banyak dipakai untuk akses kontrol dan absensi.

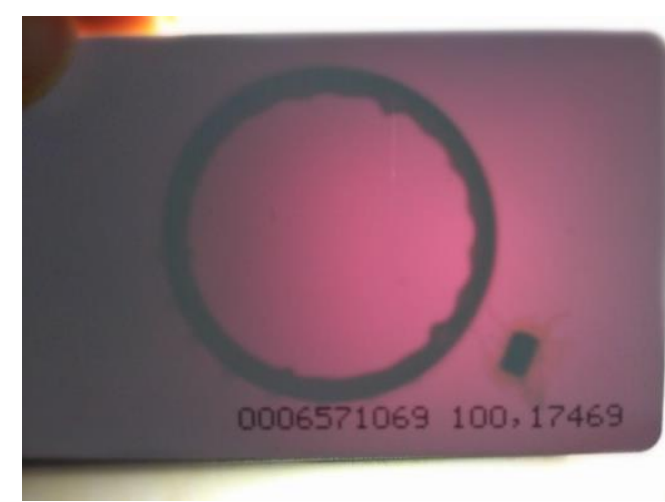

Gambar 2. Penampang kartu RFID Proximity b. Kartu RFID berfrekuensi $13,56 \mathrm{MHz}$ (High Frequency)

Kartu proximity generasi kedua ini mempunyai jangkauan kurang lebih 1 meter dan mempunyai tempat penyimpanan data. Kecuali nomor pabriknya, kita dapat membuat, mengubah, dan menghapus datanya. Kartu ini cocok untuk penggunaan masal dikarenakan tidak perlu adanya semacam server atau database yang besar untuk menyimpan data objekobjeknya. Biasanya dipakai untuk pendataan dan identifikasi tapi tidak menutup kemungkinan dipakai juga untuk akses kontrol dan absensi. Contoh kartu yang sudah beredar di Indonesia adalah E-KTP, E-Toll dan kartu MIFARE.

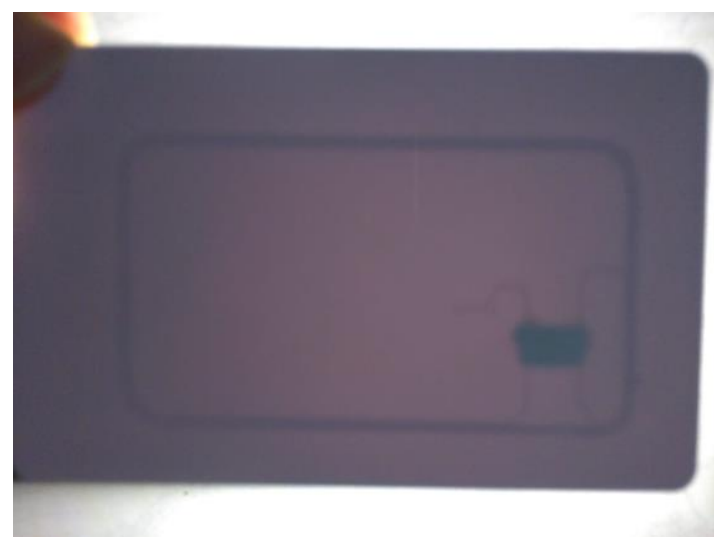

Gambar 3. Penampang kartu RFID MIFARE

\section{PEMBACA}

Untuk dapat membaca label, sistem RFID butuh sebuah perangkat bernama pembaca (reader). Singkatnya pembaca adalah sebuah perangkat untuk mendapatkan informasi dari RFID label. Pembaca mempunyai beberapa bagian inti, yaitu antena untuk mengirim atau menangkap sinyal, terminal pembaca RFID sebagai otak dari perangkatnya, serta media pembungkusnya. Seiring perkembangan zaman, pembaca RFID bisa ditambahkan fitur baru sebagai bagian tambahannya. Contoh fiturnya: Wi-Fi, Bluetooth, port HDMI, sistem GPS, Kamera, dll.

Pembaca hanya bisa menangkap dan mengirimkan satu jenis sinyal saja. Jadi jika pembaca mempunyai antena yang khusus menangkap sinyal berfrekuensi rendah, label 
berfrekuensi tinggi tidak akan terbaca. Oleh karena itu biasanya sistem RFID ini dijual secara paketan.

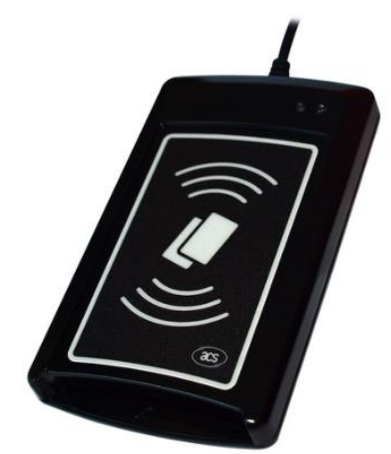

Gambar 4. Contoh Pembaca RFID khusus Proximity (Sumber: www.cardomatic.de)

Menurut mobilitasnya, pembaca RFID bisa dibagi menjadi dua kelas, tetap (fixed) dan tidak tetap (mobile). Kelas tetap biasanya digunakan untuk mengidentifikasi objek-objek yang kerap kali bergerak secara teratur dan yang digerakkan. Contohnya adalah gerbang ERP (Electronic Road Pricing), kunci pintu akses, dan alat pembaca E-KTP yang ditempatkan di kelurahan dan di kecamatan. Kelas yang lain adalah kelas tidak tetap. Merupakan pembaca RFID yang dapat dibawa kemana-mana atau mobile. Pembaca ini kerap digunakan untuk mengidentifikasikan objek-objek yang tidak bergerak dan yang bergerak secara tidak teratur. Contohnya adalah sistem RFID pada hewan ternak, stok barang di gudang, dan IFF (Idenification Friend or Foe) atau alat untuk mendeteksi identitas pesawat tempur.

Pembaca RFID punya banyak cara mendapatkan tenaganya, yaitu dengan colokan biasa, PoE (Power over Ethernet), baterai, dan aki kendaraan. PoE adalah merupakan cara mendapatkan tenaga dari kabel Ethernet atau kabel LAN. Cara ini dinilai efektif dan murah dikarenakan tidak banyak mengkonsumsi sumber daya dan hemat energi.

Dalam dunia perkantoran pembaca kelas RFID yang cocok diterapkan adalah yang tetap. Contoh penerapannya bisa dihubungkan dengan kunci pintu otomatis untuk akses keluar masuk ruangan serta keamanan atau juga bisa dipasang pada pintu utama untuk keperluan absensi.

\section{HOST}

Host merupakan tempat pengolahan data-data yang masuk dari pembaca RFIDnya. Perangkat Host sendiri bisa bermacammacam, dari yang paling simpel seperti sudah seperangkat dengan pembaca RFID sampai dengan yang menggunakan perangkat ketiga seperti PC (Personal Computer) atau Komputer.

Host perlu dihubungkan dengan pembaca untuk dapat memproses data yang masuk. Ada berbagai cara untuk menghubungkan kedua perangkat tersebut, yaitu dengan menggunakan jaringan LAN/Ethernet, jaringan nirkabel/Wifi, dan jaringan Bluetooth. Kebanyakan lingkungan perkantoran di Indonesia sudah menggunakan jaringan LAN sebagai penghubung perangkat pembaca RFID dengan PC dikarenakan mudah pengoperasiannya, akses kontrol yang lebih ketat serta lebih aman. Sedangkan jika ingin meminimalkan pengeluaran, bisa menggunakan pembaca RFID yang sudah termasuk Host dan perangkat lunaknya.

Untuk perangkat lunaknya sendiri umumnya sudah ada bawaannya dari pembaca RFID-nya. Teknisi tinggal menginstall lewat CD burn-nya atau harus unduh lewat internet.

\section{KEAMANAN}

Tidak ada suatu sistem yang benarbenar aman dari kejahatan termasuk sistem RFID. Ancaman kejahatan bisa dari pihak dalam maupun pihak ketiga dengan motif bervariasi dari yang berupa ekonomi hingga persaingan usaha sehingga perlu adanya pengawasan berkala dari level operator hingga teknisinya. Berikut adalah metode yang kerapkali digunakan penjahat untuk dapat menembus sistem keamanan RFID:

\section{a. Skimming}

Secara singkat, skimming berarti pencurian data/informasi dari media targetnya (biasanya kartu) dengan menggunakan alat yang bernama skimmer. Kebanyakan targetnya adalah kartu debit dan kartu kredit yang sudah menggunakan teknologi RFID. 
Dalam melakukan aksinya, pelaku harus mendekatkan skimmer sedekat mungkin dengan label RFID target. Jika sudah mencapai jangkauan label, otomatis data yang tersimpan dalam label akan terbaca dan tersalin ke dalam skimmer-nya.

Cara pencegahannya adalah dengan menggunakan dompet/media dengan bahan penolak sinyal radio. Serta sebisa mungkin menjauhkan diri dari seseorang yang selalu ingin mendekat tanpa alasan yang jelas.

\section{b. Spoofing}

Spoofing adalah suatu cara untuk mendapatkan akses yang tidak sah ke dalam sebuah perangkat lalu berpurapura menjadi user/anggota di dalam sistemnya. Pelakunya bisa disebut sebagai hacker atau cracker. Lain halnya dengan skimming yang menyerang label, spoofing menyerang host sistem RFID. Biasanya mereka menggunakan malware (Malicious Software) atau data perusak untuk masuk ke perangkat target. Jika sudah masuk, hacker bisa mendapatkan akses kontrol sistem, mencuri data-data berharga hingga manipulasi data.

Spoofing ada banyak macam dan metodenya. Beberapa contohnya adalah email spoofing yaitu metode yang menggunakan email palsu, umumnya mengaku berasal dari perusahaan yang sah atau pemerintah, untuk mengelabui calon korban. Biasanya disertai lampiran data yang bisa diunduh. Lampiran data ini sebenarnya adalah virus. Selain dari email, ada juga web spoofing yaitu penggunaan situs palsu, biasanya situsnya mengharuskan kita untuk memasukkan login pengguna dan kata kuncinya.

Cara pencegahannya yang paling mendasar adalah pemberian pengetahuan mengenai berbagai cara virus masuk dan menyebar, kepada tiap pegawai agar tingkat kewaspadaan a meningkat. Lalu penting untuk mengenkripsi, memvalidasi, dan membackup data-data penting. Dan terakhir, selalu pakai aplikasi anti-virus yang baik dan berlisensi agar selalu terlindungi secara otomatis dan berkala.

\section{KEUNGGULAN DAN KELEMAHAN SISTEM RFID PADA PERKANTORAN}

Sistem RFID menjanjikan banyak sekali keunggulan dalam lingkungan perkantoran. Beberapa hal yang menjadi keunggulan sistem ini adalah:

a. Dalam hal keamanan dalam, sistem ini memberikan akses kontrol hanya kepada pegawai yang berwenang saja. Hal ini bertujuan untuk membatasi kewenangan pegawai agar tidak terjadi tumpang tindih kewenangan dan berguna untuk mencegah terjadinya kejahatan dan manipulasi data oleh orang dalam. Contoh penggunaanya adalah RFIDpowered PC atau PC yang hanya bisa dinyalakan oleh orang-orang yang mempunyai hak kontrol.

b. Dalam hal keamanan luar, penggunaan sistem ini ada pada pintu akses. Pintu ini memberikan akses hanya kepada pegawai sah-nya saja dan membatasi yang tidak berkepentingan agar tetap di luar dan tidak seenaknya masuk. Pintu akses hanya dapat diakses dengan menggunakan kartu RFID yang sudah diberikan kontrol akses atau dibukakan dari dalam oleh orang dalam.

c. Dalam hal manajemen pendataan manusia, penggunaan sistem RFID bisa mencegah terjadinya manipulasi data oleh pihak manapun. Contoh paling nyata adalah penggunaan sistem ini untuk absensi harian. Dengan adanya absensi bersistem RFID, seorang pegawai yang telat atau tidak masuk tidak bisa menitipkan absen ke orang lain dengan paraf palsu.

d. Dalam hal manajemen pendataan barang, penggunaan sistem ini bisa berguna untuk mendata aset suatu perusahaan agar tidak tertukar maupun hilang. Selain itu, bisa juga untuk mendata stok gudang. Hal ini berguna untuk mencegah terjadinya pencurian barang oleh pihak manapun.

e. Dapat memberikan suasana aman dan nyaman serta menaikkan etos kerja 
pegawai-pegawainya

dikarenakan

berkurangnya gangguan dari pihak lain. Hal ini bagus untuk meningkatkan produktivitas pegawai-pegawainya.

f. Dapat meningkatkan kecepatan, keefektifitasan, dan efisiensi atau kemudahan dalam melakukan suatu pekerjaan. Contoh adalah perubahan sistem dari yang sebelumnya menggunakan cara manual atau menulis menjadi tinggal ditempelkan langsung pada alatnya saja.

Walaupun sistem ini banyak keunggulan, ada beberapa hal yang menjadi kelemahan sistem ini. Yaitu:

a. Biaya pengadaan serta maintenance yang mahal. Satu pintu akses door dengan sistem RFID proximity non-host beserta pembaca dan label-labelnya bisa menelan biaya hingga 5-10 jutaan. Biaya bisa naik lagi tergantung fitur serta penambahan perangkat yang menjadi host-nya.

b. Berkurangnya keharmonisan antar sesama pegawai maupun orang luar. Pembatasan akses kontrol bisa menyebabkan kecemburuan sosial serta minimnya interaksi sosial antar sesama pegawai maupun orang luar.

c. Terlalu bertumpu pada listrik. Untuk sistem RFID yang terhubung langsung dengan kontak listrik, sistem RFID bisa mati total jika terjadi pemutusan daya oleh sumber listrik (PLN). Pintu akses yang tidak dibekali dengan Power Supply atau generator listrik akan selalu terkunci dan tidak bisa terbuka jika tidak ada listrik.

\section{KESIMPULAN}

Sistem RFID merupakan teknologi baru di Indonesia dan seiring dengan perkembangan jaman akan terus berkembang lebih mutakhir. Dengan adanya fitur-fitur terbaru yang dapat lebih mempermudah proses, harga pun akan semakin naik.

Dalam dunia perkantoran, sistem RFID dapat memberikan dampak yang besar khususnya terhadap produktivitas, keamanan dan manajemen. Biayanya memang lebih mahal, tetapi menimbang dengan semua keunggulannya, dipastikan tidak ada yang kerugian yang berarti dan patut dicoba.

\section{DAFTAR PUSTAKA}

[1] Hamdani, Fadhilatul. "PENERAPAN RFID (RADIO FREQUENCY IDENTIFICATION) DI PERPUSTAKAAN: KELEBIHAN DAN KEKURANGANNYA." KHIZANAH ALHIMAH Vol.2 No.1, Januari-Juni 2014. Web. 23 Oktober 2019.

[2] Rane, Suhas. 2007. Rfid: Changing The face of Supply Chain Management. Hyderabad: DB DB.

[3] The Government of the Hong Kong Special Administrative Region. "RFID SECURITY." February 2008. Web. 23 Oktober 2019.

[4] Latief, Mukhlisulfatih. "SISTEM IDENTIFIKASI MENGGUNAKAN RADIO FREQUENCY IDENTIFICATION (RFID)." Saintek, Vol 5, No 1. Web. 23 Oktober 2019.

[5] "WHAT IS RFID? I THE BEGINNER'S GUIDE TO RFID SYSTEMS". AtlasRFIDStore.com. 28 Februari 2019. 26 Oktober 2019.

<https://www.atlasrfidstore.com/rfidbeginners-guide/> 